\title{
Preface to the Special Issue: Towards Improving Understanding and Prediction of Arctic Change and Its Linkage with Eurasian Mid-latitude Weather and Climate
}

\author{
Xiangdong ZHANG ${ }^{1}$, Thomas $\mathrm{JUNG}^{2}$, Muyin $\mathrm{WANG}^{3}$, Yong $\mathrm{LUO}^{4}$, Tido SEMMLER ${ }^{2}$, and Andrew $\mathrm{ORR}^{5}$ \\ ${ }^{1}$ International Arctic Research Center, University of Alaska Fairbanks, Fairbanks AK 99775, USA \\ ${ }^{2}$ Alfred Wegener Institute, Helmholtz Centre for Polar and Marine Research, Bremerhaven 27570, Germany \\ ${ }^{3}$ Joint Institute for the Study of the Atmosphere and Ocean, University of Washington, Seattle, WA 98115, USA \\ ${ }^{4}$ Center for Earth System Science, Tsinghua University, Beijing 100084, China \\ ${ }^{5}$ British Antarctic Survey, Cambridge CB3 OET, UK
}

\begin{abstract}
Citation: Zhang, X., T. Jung, M. Wang, Y. Luo, T. Semmler, and A. Orr, 2018: Preface to the special issue: Towards improving understanding and prediction of Arctic change and its linkage with Eurasian mid-latitude weather and climate. Adv. Atmos. Sci., 35(1), 1-4, https://doi.org/10.1007/s00376-017-7004-7.
\end{abstract}

The dramatic changes in the Arctic climate system during recent decades are one of the most prominent features of global climate change. Two most striking and fundamental characteristics are the amplified near-surface warming at a rate twice the global average since the mid 20th century (e.g., Blunden and Arndt, 2012; Huang et al., 2017), and the rapid decline of sea-ice extent at a pace of $12.9 \%(10 \mathrm{yr})^{-1}$ and thinning of ice thickness by $40 \%$ since 1979 (e.g., Kwok and Rothrock, 2009; Meier et al., 2012). In conjunction with these changes, the frequency of occurrence of extreme climate and weather events has ostensibly increased across the Northern Hemisphere mid-latitudes, including adverse cold spells, severe heat waves, destructive floods, and persistent droughts (e.g., Coumou and Rahmstorf, 2012). The fact that Arctic climate changes have coincided with an increase in the frequency of occurrence of extreme events has inspired broad interest in possible linkages - not only in the climate community, but also the general public, media agencies, and decision makers-in particular considering the projected future continuation and acceleration of Arctic warming and sea-ice decline (e.g., Zhang and Walsh, 2006; Zhang, 2010; Stroeve et al., 2012; Wang and Overland, 2012).

In general, it is possible that Arctic warming decreases meridional temperature gradients and thereby weakens zonal winds, which may result in a wavier jet stream and cause an increase in the occurrence frequency of extreme events (e.g., Francis and Vavrus, 2012; Cohen et al., 2014; Vihma, 2014; Overland et al., 2016). However, a strong debate has emerged, which continues until today and is partly associated with conflicting results depending on which observations or models are used and what analysis metrics are employed (e.g., Barnes, 2013; Wallace et al., 2014). The inconsistency and controversy surrounding the scientific discussion may be attributable to the complex processes and pathways of the effect of anomalous Arctic thermal forcing on the overlying atmosphere circulation dynamics and the "tug-of-war" between anomalous Arctic and tropical (or even other) forcings. At the same time, the continuing controversy has fueled numerous activities related to the possible impact of Arctic climate change on the mid-latitudes, including a series of workshops such as a National Academy of Sciences workshop in Washington DC in September 2013, a NOAA Arctic workshop in Boulder, Colorado, in May 2014, and international workshops in Reykjavik, Iceland, in November 2013; Barcelona, Spain, in December 2014; Washignton DC, USA, in Feburary 2017; and Aspen, USA, in June 2017.

In fact, research into the influence of the Arctic on midlatitude atmospheric circulation has been a long-standing topic during the last three decades [see, for example, the review by Vihma (2014)]. In this context, it is worthwhile mentioning a pioneering study from China about the impacts of anomalous Arctic sea ice on Asian monsoon circulations in the early 1990s (Huang et al., 1992). Admittedly, however, most research on atmospheric teleconnections has involved tropical-extratropical linkages associated, for example, with the El Niño phenomenon. In early studies on Arctic-mid-latitude linkages, the maximum warming anomaly considered occurred over the Eurasian landmass and the magnitude of sea-ice changes was limited. Thus, model simulations usually employed artificially exaggerated sea-ice anomalies to detect forced signals in the atmo- 
spheric circulation. However, since the mid 1990s, the amplified warming has occurred over the central Arctic Ocean and the sea-ice decline has accelerated, leading to the emergence of a new thermodynamic forcing and the conjecture that Arctic climate may have transitioned, or is going to transition, to a new state (e.g., Zhang et al., 2008; Jeffries et al., 2013).

Concurrently with this emerging Arctic forcing, linkages between the Arctic and Eurasian midlatitude weather and climate have apparently been enhanced, which could be reflected by a radical, systematic spatial shift of the hemispheric-scale atmospheric circulation (e.g., Zhang et al., 2008). Associated with this pattern shift, named the Arctic Rapid Change Pattern (ARP), the Siberian high intensifies and expands northwestward and the Aleutian low strengthens. Consequently, poleward atmospheric heat and moisture transport into the Arctic Ocean along with poleward intrusions of warm ocean water have significantly increased, which may have played decisive roles in driving the amplified central Arctic warming and accelerated sea-ice decline. At the same time, anomalous southward advection of cold polar air extends to the Eurasian mid-latitudes, which is consistent with a "warm Arctic and cold Eurasia" pattern. Note that the intensification and northwestward expansion of the Siberian high has been considered as the most conspicuous feature of the midlatitude atmospheric circulation in response to Arctic change. Studies have also identified tropospheric and stratospheric pathways, by which sea-ice-changeinduced stationary Rossby wave train propagation and troposphere-stratosphere interaction are governing mechanisms, respectively, to convey Arctic forcing signals to the mid-latitudes (e.g., Honda et al., 2009; Kim et al., 2014).

As mentioned above, changes in the atmospheric circulation and associated processes have been identified in a variety of studies. In particular, a number of recent studies employing fully coupled models have presented the ARP-like pattern in response to anomalous Arctic sea-ice forcing (e.g., Blackport and Kushner, 2017). However, controversy continues to exist. Atmosphere-only models show different responses of the Arctic Oscillation to sea-ice anomalies (Smith et al., 2017). It has also been suggested that the Eurasian cooling is a result of natural atmospheric circulation variability, instead of responses to Arctic warming (e.g., McCusker et al., 2016). The short observational record and uncertainties in prescribing forcing in numerical modeling experiments hamper progress in our understanding and prediction capability of Arctic-midlatitude linkages.

This special issue is a timely contribution to the ongoing discussion. It presents a selection of recent research outcomes that augment existing knowledge. These studies have further investigated how Eurasian, as well as North American, midlatitude atmospheric circulation and associated surface parameters respond to Arctic warming, using both statistical analysis and numerical models. Noted progress includes studying linkages from a weather or seasonal climate prediction perspective. Semmler et al. (pp. 5-13) conducted two sets of 14-day weather forecast experiments using the ECMWF model, with one set relaxed to the reanalyzed Arctic atmosphere and the other without relaxation during the model integration. They found strong Arctic-midlatitude linkage over the Eurasian and North American continents when strong stationary planetary waves are present during winter. However, when using the atmospheric stand-alone version and fully coupled version of NOAA's Climate Forecast System, version 2, Collow et al. (pp. 14-26) found that sea-ice-forced Eurasian temperature variability is not distinguishable from internal variability on the seasonal scale.

Cheung et al. (pp. 38-51) employed the singular value decomposition approach to examine the winter relationship between Arctic sea ice and atmospheric circulation properties in 11 CMIP5 models. They found that when the models show stronger sea-ice decline, weaker polar and Ferrell cells and anomalously higher sea level pressure over the Urals-Siberia region occur. At the same time, midlatitude westerlies also weaken. Han and Li (pp. 65-74) also examined CMIP5 model simulations, along with atmosphere-only model simulations. They found that winter Labrador Sea ice and SST anomalies play different roles in influencing spring precipitation in southeastern North America and western Europe. When analyzing the CMIP5 pre-industrial simulations using lead-lag regression analysis instead, Kelleher and Screen (pp. 27-37) found that an anomalously high polar cap height leads, rather than lags, a low sea-ice anomaly, suggesting that both may be attributable to enhanced midlatitude eddy heat flux, and sea-ice change may not be responsible for Eurasian cooling.

Impacts of changes in midlatitude circulation on Arctic climate are also presented in this special issue. Since August 2014, additional warming has occurred in Alaskan Arctic waters. Overland et al. (pp. 75-84) attribute this change to increased sea surface temperature in the North Pacific and associated shifts in predominant winds toward southerlies. Gian et al. (pp. 85- 
94) analyzed changes in atmospheric moisture transport, which is an important component of static energy and has recently been considered as a major player in Arctic amplification due to moisture-induced increases in cloudiness and downward longwave radiation. They found that changes in storm tracks and associated atmospheric circulation have enhanced poleward moisture transport into the Arctic Ocean.

This special issue provides new insights into the challenging question regarding the linkage between the Arctic and Eurasian mid-latitudes. However, these latest results continue to show a lack of convergence. To narrow the existing understanding, identify solid physical processes, and improve prediction capability, stronger efforts toward coordinated observations, analyses and modeling experiments have been recommended by the U.S. CLIVAR workshop on Arctic Change \& Its Influence on Midlatitude Climate and Weather (https://usclivar.org/meetings/2017-arctic-midlatitude-workshop).

Acknowledgements. Xiangdong ZHANG is a co-chair of the U.S. CLIVAR Arctic-Midlatitude Working Group and Co-lead of the task team of CliC/CLIVAR Northern Ocean Regional Panel on Advancing the Understanding of Climate Variability Due to Arcticmidlatitude Linkages. Thomas JUNG is the chair of the WWRP Polar Prediction Project and coordinator of the EU project APPLICATE. Andrew ORR is a member of the International Commission on Polar Meteorology, International Association of Meteorology and Atmospheric Sciences. The editorial team appreciates the above projects and organizations for their contribution to polar research and this special issue.

\section{REFERENCES}

Barnes, E. A., 2013: Revisiting the evidence linking Arctic amplification to extreme weather in midlatitudes. Geophys. Res. Lett., 40, 4734-4739, https://doi.org/10.1002/grl.50880.

Blackport, R., and P. J. Kushner, 2017: Isolating the atmospheric circulation response to Arctic sea ice loss in the coupled climate system. J. Climate, 30, 2163-2185, https://doi.org/10.1175/JCLI-D-16-0257.1.

Blunden, J., and D. S. Arndt, 2012: State of the climate in 2011. Bull. Amer. Meteor. Soc., 93, S1-S282, https://doi.org/10.1175/2012 BAMSStateoftheClimate.1.

Cohen, J., and Coauthors, 2014: Recent Arctic amplification and extreme mid-latitude weather. Nature Geoscience, 7, 627-637, https://doi.org/10.1038/ngeo2234.

Coumou, D., and S. Rahmstorf, 2012: A decade of weather extremes. Nature Climate Change, 2, 491-496, https://doi.org/10.1038/ NCLIMATE1452.

Francis, J. A., and S. J. Vavrus, 2012: Evidence linking Arctic amplification to extreme weather in mid-latitudes. Geophys. Res. Lett., 39, L06801, https://doi.org/10.1029/2012GL051000.

Honda, M., J. Inoue, and S. Yamane, 2009: Influence of low Arctic sea-ice minima on anomalously cold Eurasian winters. Geophys. Res. Lett., 36, L08707, https://doi.org/10.1029/2008GL037079.

Huang, J. B, and Coauthors, 2017: Recently amplified arctic warming has contributed to a continual global warming trend. Nature Climate Change, https://doi.org/10.1038/s41558-017-0009-5.

Huang, S. S., X. Q. Yang, and Q. Xie, 1992: The effects of the Arctic sea ice on the variations of atmospheric general circulation and climate. Acta Meteorologic Sinica, 6, 1-14.

Jeffries, M. O., J. E. Overland, and D. Perovich, 2013: The Arctic shifts to a new normal. Physics Today, 66, 35-40, https://doi.org/ 10.1063/PT.3.2147.

Kim, B.-M., S.-W. Son, S.-K. Min, J.-H. Jeong, S.-J. Kim, X. D. Zhang, T. Shim, and J.-H. Yoon, 2014: Weakening of the stratospheric polar vortex by Arctic sea-ice loss. Nature Communications, 5, 4646, https://doi.org/10.1038/ncomms5646.

Kwok, R., and D. A. Rothrock, 2009: Decline in Arctic sea ice thickness from submarine and ICESat records: 1958-2008. Geophys. Res. Lett., 36, L15501, https://doi.org/10.1029/2009GL039035.

McCusker, K. E., J. C. Fyfe, and M. Sigmond, 2016: Twenty-five winters of unexpected Eurasian cooling unlikely due to arctic sea-ice loss. Nature Geoscience, 9, 838-842, https://doi.org/10.1038/ngeo2820.

Meier, W. N., J. Stroeve, A. Barrett, and F. Fetterer, 2012: A simple approach to providing a more consistent Arctic sea ice extent time series from the 1950s to present, The Cryosphere, 6, 1359-1368, https://doi.org/10.5194/tc-6-1359-2012.

Overland, J. E., and Coauthors, 2016: Nonlinear response of mid-latitude weather to the changing Arctic. Nature Climate Change, 6, 992-999, https://doi.org/10.1038/nclimate3121. 
Smith, D. M., N. J. Dunstone, A. A. Scaife, E. K. Fiedler, D. Copsey, and S. C. Hardiman, 2017: Atmospheric response to Arctic and Antarctic sea ice: The importance of ocean-atmosphere coupling and the background state. J. Climate, 30, 4547-4565, https://doi.org/10.1175/JCLI-D-16-0564.1.

Stroeve, J. C., V. Kattsov, A. Barrett, M. Serreze, T. Pavlova, M. Holland, and W. N. Meier, 2012: Trends in Arctic sea ice extent from CMIP5, CMIP3 and observations. Geophys. Res. Lett., 39, L16502, https://doi.org/10.1029/2012GL052676.

Vihma, T., 2014: Effects of Arctic sea ice decline on weather and climate: A review. Surveys in Geophysics, 35, 1175-1214, https://doi.org/10.1007/s10712-014-9284-0.

Wallace, J. M., I. M. Held, D. W. J. Thompson, K. E. Trenberth, and J. E. Walsh, 2014: Global warming and winter weather. Science, 343, 729-730, https://doi.org/10.1126/science.343.6172.729.

Wang, M. Y., and J. E. Overland, 2012: A sea ice free summer Arctic within 30 years: An update from CMIP5 models. Geophys. Res. Lett., 39, L18501, https://doi.org/10.1029/2012GL052868.

Zhang, X. D., 2010: Sensitivity of Arctic summer sea ice coverage to global warming forcing: Towards reducing uncertainty in Arctic climate change projections. Tellus A, 62, 220-227, https://doi.org/10.1111/j.1600-0870.2010.00441.x.

Zhang, X. D., and J. E. Walsh, 2006: Toward a seasonally ice-covered Arctic Ocean: Scenarios from the IPCC AR4 model simulations. J. Climate, 19, 1730-1747, https://doi.org/10.1175/JCLI3767.1.

Zhang, X. D., A. Sorteberg, J. Zhang, R. Gerdes, and J. C. Comiso, 2008: Recent radical shifts of atmospheric circulations and rapid changes in Arctic climate system. Geophys. Res. Lett., 35, L22701, https://doi.org/10.1029/2008GL035607. 